\title{
Building Walls: Trump Election Rhetoric, Bullying and Harassment in US Schools
}

\section{Paul Horton}

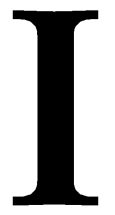

n the midst of the 2016 US presidential election, reports began surfacing of bullying and harassment in schools that could be linked to the divisive rhetoric of the presidential nominee, Donald Trump. In April 2016, for example, the Southern Poverty Law Center published the findings of a survey of approximately 2,000 K-12 teachers in the US. The report was titled Teaching the 2016 election: The Trump Effect and suggested direct links between Trump's election rhetoric and the prevalence of school bullying and harassment in US schools (Costello, 2016a). A number of newspaper articles were published in the wake of the report that suggested that Trump was "making America meaner" by "mainstreaming hate" (Kristof, 2016) and that his rhetoric was fuelling "school bullies" across the country (Carroll, 2016). Indeed, numerous newspaper articles published in the lead up to the Presidential election suggested not only that the "Trump effect" was leading to more bullying in schools (e.g., CBS Detroit, 2016; Jones, 2016), but that Trump himself was a "bully" (e.g., Loeb, 2016; Schwartzmann \& Miller, 2016; Washington Post Editorial Staff, 2016).

Following Trump's election victory, the Southern Poverty Law Center conducted an online survey of more than 10,000 school staff and found that racial targeting and harassment had "skyrocketed", and that it "was most frequently reported by educators in schools with a majority of white students" (Costello, 2016b, p.6). Likewise, in a study of more than 50,000 young people between the ages of 13 and 18, the Human Rights Campaign Foundation (2017) found 
that 70 percent had observed bullying, harassment or hate messages since the election began and that these were often motivated by race or immigration status. Almost two-thirds of those who had witnessed harassment said, "at least one incident was definitely because of the election" (Human Rights Campaign Foundation, 2017, p.6). Reports in the media likewise suggested that incidents of bullying and harassment increased in the wake of the election (e.g., Jamieson, 2016; Lanktree, 2016; McDonald, 2016; Miller, 2017). According to Huang and Cornell (2019), there were "more than 50 news reports of school bullying since the election in which students made statements linked to the newly elected president" (p.69). Highlighting the increased number of reports circulating in the media, Meyer (2016) pointed out in Psychology Today: "I have been researching and writing about biased harassment in schools since the early 90's and never have I seen so many documented incidents covered in the media in such a short period of time." It is unclear, however, whether the increase in reported incidents reflects an increase in bullying and harassment because of the "Trump effect." As Huang and Cornell (2019) have pointed out, it is difficult to determine whether Trump's election rhetoric influenced the prevalence of bullying in schools or whether it led to "a shift in the form of bullying rather than an increase in prevalence" (p.69).

Despite some discussion of how election rhetoric may "trickle down" to students and influence bullying in schools (e.g., Bennett, 2017; Johnson, 2017), there has been little analysis of the process through which this occurs. A few authors have suggested that Bandura's social learning theory can help us better understand how bullying practices are modelled on the behaviour of significant role models, such as presidential candidates or presidents (e.g., Huang \& Cornell, 2019; Sprague, 2016). According to social learning theory, aggressive behaviour is socially learned through modelling, mediated via cognitive processes, and reinforced, either directly, vicariously, or through self-reinforcement (Bandura, 1973). In understanding aggressive behaviour, then, it is not enough to focus on the inner emotions of individuals. Rather, as Bandura (1973) suggested, it is necessary to consider how such behaviour is encouraged societally and socially, "by valuing 
aggressive accomplishments, furnishing successful aggressive models, and ensuring that aggressive actions secure rewarding effects" (p.59).

One way in which to consider how bullying and harassment are encouraged societally and socially is by conceptualising bullying as a social-ecological phenomenon. While school bullying researchers have increasingly drawn upon Bronfenbrenner's $(1977,1979)$ social-ecological model to conceptualise bullying (e.g., Espelage \& Swearer, 2010; Hong \& Espelage, 2012), studies of school bullying utilising the social-ecological model have tended to restrict themselves to the microsystem (e.g., peer relations) and, to a lesser extent, the mesosystem (e.g., family or school influences) (Bouchard \& Smith, 2017; Carrera et al., 2011; Horton, 2016a; Huang \& Cornell, 2019). Despite some commentary on the importance of discourse to school bullying (e.g., Horton, 2016b; Walton, 2011, 2015), there has been a lack of empirical consideration of the importance of the exosystem (e.g., the role of the mass media), the macrosystem (e.g., the influence of dominant societal norms and values), or the chronosystem (e.g., the temporal context) (Bouchard \& Smith, 2017; Horton, 2016a; Huang \& Cornell, 2019). Espelage and Swearer (2010) have argued that while the "social-ecological framework illustrates the intricacy of human behavior, it is more difficult to empirically examine this complexity, particularly at the macrosystem level" (p.62).

Put another way, there is a perceived difficulty in examining the ways in which interactional norms at the microsystem level, or what Goffman (1983) termed "the interaction order", are influenced by discursive norms at the macrosystem level, or what Foucault (1981) termed "the order of discourse". The concept of the order of discourse has been used in Critical Discourse Analysis to refer to "a potentially conflictual configuration of discourses within a given social field" (Jørgensen \& Phillips, 2002, p.72). The order of discourse influences communication by delimiting which genres and discourses are available for communication within a particular field. However, it is also subject to change, depending on how those communicating use such genres and discourses, and on whether orders of discourse from other domains are incorporated into 
"communicative events" such as political speeches or election debates (Jørgensen \& Phillips, 2002, p.67). Communicative events are made up of three different components: text (i.e., what is said, written and/or portrayed), discursive practice (i.e., the practice through which the text is produced and consumed), and the social practices that influence (e.g., US border politics or the presidential election), and are influenced (e.g., school bullying and harassment) by the text and mediated by the discursive practice (Fairclough, 2010; Jørgensen \& Phillips, 2002).

In this essay, I utilise Critical Discourse Analysis and draw on Bronfenbrenner's $(1977,1979)$ social-ecological model in order to consider in more depth the relationship between Trump's election rhetoric about the need for a border wall and the social practices of bullying and harassment in schools across the US. In doing so, I illustrate not only the ways in which interactional norms at the microsystem level are influenced by discursive norms at the macrosystem level, but also how dominant bullying discourses shift focus away from the outer layers of the social-ecological model and reduce the problem to one of individual behaviour at the microsystem level. The communicative events that I analyse include Trump's announcement of his presidential bid on June 16, 2015, a subsequent statement issued by Trump on July 6, 2015, a Trump rally in Anaheim, California on May 25, 2016, and the second and third presidential debates in Saint Louis (October 9, 2016) and Las Vegas (October 19, 2016).

The social practices that I analyse were reported in newspaper articles published between June 16, 2015 and June 16, 2017. The newspaper articles were found via a Google news search using the key words "students build that wall." The search resulted in more than 250 newspaper articles, but I stopped considering articles after the first 100, due to repetition and a sharp decrease in relevance. Of the 100 articles, 47 were deemed relevant for the study. While this was by no means a comprehensive search and does not therefore indicate the prevalence of school bullying and harassment during the two-year period following Trump's announcement of his candidacy, it does nevertheless provide a useful snapshot of the forms of social practice that occurred in 
schools during that time. In this essay, I focus particularly on the case of Royal Oak Middle School, which was the focus of more than a quarter of the articles, but also consider other social practices that occurred prior to it at other schools in order to highlight the ways in which social practice feeds back into discursive practice via media reports.

\section{Calling for the wall to be built and positioning Mexicans as the 'other'}

The idea of building a wall on the US-Mexico border was reportedly initiated as a mnemonic device by Trump's advisors, Roger Stone and Sam Nunberg, to remind Trump to talk about taking a tough stance on immigration (Anderson, 2019; Hirschfeld Davis \& Baker, 2019). The first time Trump discussed the idea was at the Iowa Freedom Summit on January 24, 2015 (Anderson, 2019). Four minutes into his speech, Trump pointed to the need to "build a fence" in order to stop people walking across the US-Mexico border, and suggested that if he ran for President and was elected, he would "start by building a very, very, powerful border" (C-Span, 2015).

While Trump did not directly name Mexico or Mexicans in his Iowa Freedom Summit speech, when he later announced his Presidential bid at Trump Tower in New York City on June 16, 2015, it took him less than two minutes to begin pointing at Mexico as the origin of the "problem":

When do we beat Mexico at the border? They're laughing at us, at our stupidity. And now they are beating us economically. They are not our friend, believe me. But they're killing us economically. The US has become a dumping ground for everybody else's problems [applause]. Thank you. It's true, and these are not the best and the finest. When Mexico sends its people, they're not sending their best. They're not sending you [pointing]. They're not sending you [pointing]. They're sending people that have lots of problems, and they're bringing those problems with them. They're bringing drugs. They're bringing crime. They're rapists. And some, I assume, are good people. But I speak to border guards and they tell us what we're getting. And it only makes sense. They're sending us not the right people. (Washington Post Staff, 2015). 
In this extract of his speech, Trump's polarising rhetoric constructs oppositional relations between the US and Mexico, between "us" and "them", with Mexico positioned as "beating" and "killing" the US economically. Relationally, Mexico is not the US's "friend" and the Mexicans being sent are "not the right people" and not "their best". They are not like the Americans in the audience. Rather, they have "lots of problems", which they are bringing with them, and are "rapists." Trump puts forward his statements as facts through the use of the relational "are". While he hedges his comments with the statement "And some, I assume, are good people", the message is clear: Mexico and Mexicans constitute a threat to the well-being of the US and Americans. Indeed, Trump follows up the comment about some being good people, by using "but" and providing the expert testimony of border guards to discredit the possibility that the Mexicans being sent are good people. The US is positioned metaphorically as a "dumping ground for everybody else's problems", suggesting that the Mexicans entering the US are human garbage.

Later in the announcement, Trump pointed to the lack of jobs in the US, to Mexico's increasingly dominant economic position, and to his intention to increase import taxes as a means to force car manufacturing companies to shift production back to the US. Towards the end of the announcement, Trump reiterated that he would "do various things very quickly" if he was elected president (Washington Post Staff, 2015). One of the issues at the top of his todo list was to build a "great wall" on the US-Mexico border and to get Mexico to cover the costs. As Trump put it:

I would build a great wall, and nobody builds better walls than me, believe me, and I'll build them very inexpensively, I will build a great, great wall on our southern border. And I will have Mexico pay for that wall (Washington Post Staff, 2015).

Trump was subsequently challenged in the media about his views about Mexicans (e.g., CNN, 2015). In response to what he perceived as his speech being "deliberately distorted by the media" (Walker, 2015), Trump issued a statement on July 6, 2015, wherein he clarified his views: 
What can be simpler or more accurately stated? The Mexican Government is forcing their most unwanted people into the United States. They are, in many cases, criminals, drug dealers, rapists, etc. ... In other words, the worst elements in Mexico are being pushed into the United States by the Mexican government. The largest suppliers of heroin, cocaine and other illicit drugs are Mexican cartels that arrange to have Mexican immigrants trying to cross the borders and smuggle in the drugs. The Border Patrol knows this. Likewise, tremendous infectious disease is pouring across the border. (Walker, 2015).

Here, Trump again attributes negative processes to Mexico, in terms of "forcing" and pushing their "most unwanted people" and "the worst elements" into the US. Once again, the US is portrayed as the unfortunate recipient, while Mexicans are portrayed as "criminals", "drug dealers", and "rapists" with "tremendous infectious disease", which is "pouring across the border." In order to emphasise the factual status of what he is saying, Trump once again adds expert testimony in the form of the border patrol, who also "know" what Trump is saying.

At Trump rallies across the country, Trump repeatedly reiterated his intention to build a wall. At a rally in Anaheim on May 25, 2016, for example, Trump talked about how 16,500 border patrol agents had endorsed him and that he had asked "one of the top people" about the problem of illegal immigration and the importance of the wall:

They said, "Mr Trump, you have no idea. We have the equipment, we have everything, we're told to stand back and let people just flow across like Swiss cheese", ok. I said to him, "So, I think we need the wall. How important is the wall?" To the border patrol people. They said, "Mr Trump, it's absolutely vital.” And, actually, the one man said something that was interesting. He said, "It's an absolutely important tool. Maybe our most important tool to stop what's going on, Mr Trump.” (Fox10 Phoenix, 2016).

By asserting that the conversation he had was with "one of the top people", Trump assures the audience that the man has the necessary information to comment on the problem and that what the man said is important. Trump then quotes the man as saying that the border patrol "have the equipment", they "have 
everything", but that they are told (presumably by the Obama administration) "to stand back and let people just flow across like Swiss cheese". Even if Swiss cheese does not flow, Trump uses the metaphor to state that people (i.e., Mexicans), much like the "tremendous infectious disease" referenced in his clarificatory statement, are flowing across the border and that a border wall is thus needed to stem the tide. In contradiction to the statement that they already have the necessary equipment, that they have "everything", Trump then quotes the man as saying the wall is "absolutely vital", "an absolutely important tool", and uses this contradictory assertion to justify his plans to build a wall. Trump finished his speech by saying, "We're going to build the wall, we have no choice. We have no choice." In response, Trump supporters began chanting "Build that wall!" Trump grinned, put two thumbs up, and then joining in, chanting "Build that wall!", eight times, getting louder each time (Fox10 Phoenix, 2016).

During the second presidential debate in Saint Louis on October 9, 2016, in response to Hillary Clinton's critique of his proposed Muslim ban, Trump spoke about the threat of illegal immigrants:

\begin{abstract}
Hilary Clinton, in terms of having people come into our country, we have many criminal illegal aliens. When we want to send them back to their country, their country says we don't want them. In some cases, they're murderers, drug lords, drug problems. And they don't want them. And Hillary Clinton, when she was secretary of state, said that's OK, we can't force them into their country. Let me tell you, I'm going to force them right back into their country. They're murderers and some very bad people ... we are letting people into this country that are going to cause problems and crime like you've never seen. We're also letting drugs pour through our southern border at a record clip. At a record clip. And it shouldn't be allowed to happen. (Transcript of the second debate, 2016).
\end{abstract}

Here, Trump positions himself in opposition to the supposedly open-door policy advocated by Clinton, stating that he will force the "many criminal illegal aliens" residing in the US "right back into their country". Continuing the theme from his presidential campaign announcement, Trump states that their country does not want them, and hence that they are not the right kind of people. Using the term "aliens", Trump reinforces the view that they are not 
"one of us"; that they are as different from "us" as humanly possible (Mehan, 1997). He initially hedges his judgement of them by stating "in some cases", before painting them as "murderers", "drug lords", "drug problems", "very bad people", who "are going to cause problems and crime like you've never seen." By referencing the drugs pouring through the southern border, Trump also makes it clear that he is referring particularly to those illegal immigrants crossing over from Mexico to the US.

During the third, and final, presidential debate in Las Vegas on October 19, 2016, Trump again raised the issue of illegal immigrants, drugs, and the need for "strong borders":

In the audience tonight, we have four mothers of, I mean, these are unbelievable people that I've gotten to know over a period of years whose children have been killed, brutally killed by people that came into the country illegally. You have thousands of mothers and fathers and relatives all over the country. They're coming in illegally. [...] One of my first acts will be to get all of the drug lords, all of the bad ones, we have some bad, bad people in this country that have to go out. We're going to get them out; we're going to secure the border. And once the border is secured, at a later date, we'll make a determination as to the rest. But we have some bad hombres here, and we're going to get them out. (Blake, 2016).

Here, Trump engages in a form of storytelling, recounting the personal negative experiences of four mothers in the audience (Van Dijk, 1993). In doing so, he assures the audience that he has "gotten to know" them, and that he can thus judge their "unbelievable" character, before then informing the audience that the mothers' children "have been killed, brutally killed" by illegal immigrants. He then informs the audience that it is not only these mothers suffering at the hands of illegal immigrants, but that there are "thousands of mothers and fathers and relatives all over the country." Once again, he associates illegal immigrants with drugs and violence, and refers to them as "bad, bad people" who "have to go out" of the country. Trump then states that once "all of the bad ones" have been removed and the border secured, they will "make a determination as to the rest." Here, Trump makes direct connections to Mexicans, and Hispanic people more generally, through the use of the denigrating label "bad hombres"; suggesting 
that a secure border would not only keep out "all of the bad ones" but potentially even "the rest".

In the above communicative events, Trump draws on a number of orders of discourse to negatively depict Mexicans, including an immigration discourse (e.g., "illegal aliens"), a trade war discourse (e.g., "killing us economically", "beating us economically"), a war on drugs discourse (e.g., "drug lords", "drug dealers", "drug problems"), a war on disease discourse (e.g., "tremendous infectious diseases", "rapists"), and a war on crime discourse (e.g., "criminals", "crooks", "murderers", "rapists"). Mexicans are thus portrayed as embodying a raft of problems and being the "wrong" kind of people. Indeed, they are portrayed as "not the right people", "not the best", "the worst elements", "bad hombres", "bad, bad people", and essentially human garbage that is being dumped into the US. By drawing on multiple discourses, Trump does not simply position Mexicans as a problem, but rather as the problem, incorporating the ills of American society (e.g., unemployment, crime, sickness, and drug abuse). He depicts an "us" vs. "them" relationship, with "them" positioned as the enemy, as "outside of society" and thus not "one of us" (Mehan, 1997, p.258).

By connecting Mexicans and Mexico-US immigration to issues such as drugs, crime, unemployment, and disease, Trump not only draws on various orders of discourse but nourishes them and promotes them as acceptable forms of communication (Mehan, 1997). In doing so, he not only speaks to an adult electorate but also models behaviour for school-aged children across the country, reinforcing social difference and vicariously reinforcing negative social practice.

\section{Building walls and bullying the 'other'}

Prior to the election, the name 'Trump' and variations of his call for the wall to be built were used to communicatively build walls at schools in states across the US. The Los Angeles Times reported on February 26, 2016, for example, that high school students from a high school in Des Moines, Iowa, chanted "Trump!" and "Build that 
wall!" at the end of a boys' basketball match between the largely white high school and a more racially diverse high school (Schilken, 2016). Similar incidents were also reported at high schools in Indiana and Wisconsin in March and April (e.g., CBS New York, 2016; Cuevas, 2016).

The name Trump and the words "Build that wall" (or variations of that) were not only the focus of chants but were also reportedly used as the basis for graffiti. In April 2016, for example, the words "Trump 2016" and "Build that wall" were spray-painted on a "spirit rock" at a school in Connecticut (Iannetta, 2016), while in October, the words "Trump", "Trump 2016" and "Build the wall higher" were spray-painted on rubbish bins, doors and walls at a school in Windsor, California (Brinkley, 2016; Tan, 2016). In May 2016, a banner with the words "Build a Wall" was hung in the hallway of a high school in Oregon, leading to a number of student protests at schools throughout the state (Crombie, 2016; Fuller, 2016; Parks, 2016). During one such protest in Portland the following week, a student participating in the protest was reported as saying, "They tell me I'm a gang member, that I'm here to deal drugs ... No, I'm here to get an education. And to be someone in life" (Parks, 2016). This student highlights the links between the "build a wall" rhetoric and the discourse about Mexicans and Latinos being gang members and drug dealers, which was also utilised by Trump during his Presidential campaign.

In June 2016, students built a wall out of boxes to block access to a common area in a school in North Carolina. A photo was shared on Instagram with the caption "We built the wall first" and other students shared the photo with the hashtags \#buildthatwall and \#thewallwillgoup (Donovan, 2016). In September, students at a high school in Colleyville, Texas, posed with a large poster of a wall with the words "paid for by Trinity" during a "Make Colleyville Great Again" pep rally. The poster was referencing Trinity High School, a rival school with a large number of Latino students, and Trump's claim that Mexico would pay for the wall (Latimer, 2016). Students from a high school cheer block in Warsaw, Indiana were also forced to shut down their Twitter account in September after 
posting tweets with the hashtags \#buildthatwall and \#redwhiteandbetter[than]you (Seltzer, 2016).

The day after Trump's election victory, numerous incidents were reported in the media. For example, a chalk drawing of a wall was drawn on the ground at a school in Plano, Texas, with the words "Build that Wall", "Can't stop Trump" and "Hilary for Prison" written in chalk next to it (Mansoor, 2016). In New Braunfels, Texas, students chanted "build a wall" on a school bus (Santos, 2016). In DeWitt, Michigan, students at a junior high school formed a human wall to stop minority students from passing by and getting to their lockers (Durr, 2016), while in Royal Oak, Michigan, seventh grade (12-13-year-olds) students were video-recorded chanting "Build a wall!" in the school cafeteria of Royal Oak Middle School (Jacobo, 2016; Wallace \& LaMotte, 2016). The video footage was recorded on a phone by a 12 -year-old Mexican American girl, who explained in an interview with $\mathrm{CNN}$ :

It was so hard because these are my friends, and I see them just saying these awful things and it was so hard to look and just watch, and not be able to do anything because I was afraid (Wallace \& LaMotte, 2016).

The girl said this was not the first time that she had experienced racism at the school and that she had reported earlier incidents to school staff but felt that no-one had listened to her, so she decided to record the chanting to have some evidence, "so it wouldn't be my word against theirs" (Wallace \& LaMotte, 2016). She also texted the video to her mother, who then sent the video to some other parents, one of whom then shared the video on Facebook (Wallace \& LaMotte, 2016). The mother who posted the video on Facebook captioned it with the words:

This happened today at Royal Oak Middle School in Royal Oak, Michigan. It is so sad. Latino children were crying. The taunts, the "Build that Wall" with such bullying power and hate from children to children. Just Horrifying! (Stafford, 2016).

This caption reflects not only the ways in which incidents of harassment may be conflated with bullying, but also how bullying 
behaviour is commonly reduced to the supposedly hateful behaviour of individuals or groups of individuals. This focus on the negative behaviour of individuals and calls for disciplinary sanctions was also illustrated by a Facebook user, who wrote, "All those kids need to be disciplined. I would be so disappointed if I found out my daughter was part of that group" (Stafford, 2016). However, highlighting that "hateful" behaviour is something that is socially learned another Facebook user wrote:

This is not the result of the election!!! Hate is not born with us, it is taught in our homes and communities!!! These kids didn't just learn to bully others and put them down in one day!!! They learned from their parents and their teachers (Stafford, 2016).

What is notable in the above comment is that while this user points to behaviour being socially learned, they also state that it is not the result of the election.

The school principal posted a video message to students, wherein he referred to the cafeteria "incident", which he said caused classmates and members of the Royal Oak community to "feel alienated and unwelcome" (Jacobo, 2016). He stated that because "this incident, brief though it may have been, made people feel unsafe, it was an incident that requires an unequivocal response from all of us" (Jacobo, 2016). In doing so, he reduced the issue of racial harassment to a singular, "brief" "incident", and subsequently suggested that it did not reflect the character of students at Royal Oak Middle School (ROMS). As he put it, "ROMS, this is not who we are" (Jacobo, 2016). He called on teachers and staff to go to lunch that day and "sit down, grab a bite with kids, and talk to them. Engage in meaningful dialogue", because as he put it, "Our students are awesome, and I want you to see that they're awesome all day long" (Jacobo, 2016). Here the focus is on the character of the students, who made a "brief" mistake, but are otherwise "awesome all day long" (Jacobo, 2016).

The Superintendent of Royal Oak Schools also made a statement that day about a "small group of students" involved in an "incident" in the cafeteria. He stated that the school "addressed this incident 
when it occurred" and that they are working with their students "to help them understand the impact of their words and actions on others in their school community" (Stafford, 2016). Once again, the social practice was reduced to a brief "incident" involving a "small group of students", with the emphasis on teaching students to "understand the impact of their words and actions".

The following week, a noose was found hanging in a boys' bathroom of the same school (Wallace \& LaMotte, 2016). The police were called to the school, because as the superintendent stated, "an incident of that magnitude goes beyond just school discipline". The student responsible was subsequently expelled and a school assembly was held (Wallace \& LaMotte, 2016). While the noose "incident" was swiftly dealt with, there appears to have been little or no discussion of how the noose was connected to the cafeteria "incident", to the election rhetoric of Trump, whereby he repeatedly referred to Mexicans as "criminals", "crooks", and "rapists", or to anti-Clinton chants of "hang the bitch" at Trump rallies (e.g., Crowley, 2016). Such links were alluded to when the girl who filmed the chanting spoke about the fear she felt when the noose was found. As she put it, "I was terrified. I was so scared that they were going to hurt me or [my friend]" (Wallace \& LaMotte, 2016).

Rather than focusing on the discursive practice being drawn upon in the social practices, some parents instead reportedly blamed the girl for causing the ensuing controversy around the issue and called for her to be suspended or expelled for filming the incident involving their children (Herman, 2016; Wallace \& LaMotte, 2016). As the girl's friend said in the interview with CNN, "They're saying that it's [her] fault for taking the video, that this never would have happened if she didn't take it" (Wallace \& LaMotte, 2016). The friend's mother, who worked at the school, explained that "People were pointing the finger and saying she should be expelled, and she should be prosecuted for endangering children" (Wallace \& LaMotte, 2016). The girl subsequently moved to a private school because of her experiences. As she explained: 
I was tired of how they were treating me. I couldn't take it any longer. They would glare at me. People would see me in the hallways and turn around and walk the other way ... I felt like an animal (Wallace \& LaMotte, 2016).

Here, the girl highlights the ways in which an "incident" of racial harassment in the school cafeteria developed into a bullying situation, whereby she was blamed for recording the harassment, glared at and excluded by her peers, and subjected to a form of dehumanisation, to the extent that she "felt like an animal."

\section{The importance of discourse to destructive social practices}

At the macrosystem level, discourses related to anti-immigration, international trade, and wars on drugs, disease and crime provided the referential backdrop for Trump's speeches about Mexicans, Mexico-US immigration, and the need for a wall. Since Trump first announced he was running for president on June 16, 2015, he repeatedly associated Mexicans and other immigrant groups with negative processes and referred to them in terms of illegality and badness (as in "bad, bad people" and "bad hombres"). He positioned them as "not the right people" and referred to them as drug dealers, gang members, criminals, rapists, murderers, and the carriers of "tremendous infectious disease". In doing so, he drew upon supposed expert testimony and personal experiences to strengthen the perceived truthfulness of his assertions.

Trump did not invent these discourses about Mexicans but rather engaged in a discursive practice based on stereotypical depictions of Mexicans in his pursuit of political power. When politicians speak negatively about minority groups, they do not necessarily do so in order to simply speak their mind, but rather do so with the aim of manipulating public opinion (Van Dijk, 1993). As McLeod (1999, p.360) has pointed out, presidential elections can be understood as "sociodramas" involving "symbolic manipulation by design, playing on deeply held beliefs in the electorate." Put another way, Trump's rhetoric provided a "smoke screen" to hide the political ends being forwarded (Johnson, 2010, p.987). 
While it is unclear to what extent Trump's rhetoric directly influenced the prevalence of racial harassment and bullying in schools across the US (Huang \& Cornell, 2019), Trump nonetheless modelled negative behaviour by reinforcing racialised social difference. This is evident through the use of the words "Trump", "Trump 2016", and variations on the phrase "build that wall". However, as Huang and Cornell (2019) have pointed out, it is unlikely that large numbers of school-aged children were closely following Trump's statements. Rather, these statements were filtered through the news media and social media in the exosystem, and the views expressed by parents, teachers, siblings and peers in the mesosystem and microsystem. The ways in which this was done will have provided signals about the appropriateness of Trump's rhetoric and influenced the likelihood of this rhetoric being reproduced in the microsystem of the school.

The social practices discussed in this essay demonstrate not only the ways in which Trump's divisive rhetoric influenced the content of the social practice, but also how these social practices fed into the order of discourse and perpetuated the use of such divisive rhetoric. Not only did Trump's name come to signify anti-Mexican and anti-immigrant sentiment, but his calls for a wall to be built found their way into daily discourse in varying forms. The reporting of social practices of bullying and harassment in the media most likely also served to perpetuate the pro-wall discourse which was referenced in the chanting that took place in the cafeteria of Royal Oak Middle School. Such connections highlight the importance of the macrosystem and suggest that rather than focusing on race and ethnicity as individual level predictors of bullying behaviour (e.g., Hong \& Espelage, 2012), it is necessary to consider the importance of discourse and the ways in which racial harassment and bullying are contextually and historically situated at the macrosystem and chronosystem levels.

The statements of the principal and the superintendent highlight how the dominant bullying discourse places focus on the behaviour and character of individuals rather than a more extensive consideration of the ways in which social practices are influenced 
by discursive practices (Horton, 2016b; Walton, 2011, 2015). The statements also illustrate how bullying and harassment are often treated in terms of individual incidents that need to be dealt with, rather than as part of broader power relations. The girl's recording of the chanting, her sharing of the video with her mother, her mother's sharing of the video with other parents, the sharing of the video on Facebook, the hangman's noose, the calls for the girl to be expelled, and her bullying by her peers, highlight the ways in which the social-ecological systems are interconnected and how, rather than bullying simply trickling down from the macrosystem to the microsystem, what happens at the microsystem level can also influence what happens at the mesosystem, exosystem, and potentially even the macrosystem level.

The girl's experiences of harassment and bullying highlight Walton's (2011, p.140) argument that school safety issues are often dealt with in terms of individual behavioural issues, rather than in relation to the "collective social, cultural, and political anxieties" they reflect. As Walton (2011, p.140) notes, "Bullying often reflects larger social and political battles, moral panics, and collective anxieties", and it is thus important to critically address the ways in which norms and values at the macrosystem level are reinforced through the discursive and social practices of presidents, politicians, parents, teachers, siblings, peers and others. Indeed, it is necessary to consider the importance of discourse to destructive social practices of harassment and bullying in schools. The walls that were rhetorically constructed through chanting in the cafeteria of Royal Oak Middle School were built on a foundation of anti-immigrant sentiment and commissioned by a presidential candidate who himself chanted "build that wall" and used the discourse of the wall in his pursuit of presidential office. 


\section{References}

Anderson, S. (2019, 4 January). Where the Idea for Donald Trump's Wall Came From. Forbes. From https://www.forbes.com/sites/stuartanderson/2019/01/ 04/where-the-idea-for-donald-trumps-wall-camefrom/\#68fc4fe14415

Bandura, A. (1973). Aggression: A Social Learning Analysis. New Jersey: Prentice Hall.

Bennett, A. (2017, 16 January). Did Donald Trump or the 2016 Election Cause More Bullying in Schools? The News \& Observer. From https://www.newsobserver.com/news/local/education/ar ticle126802779.html

Blake, A. (2016, 19 October). The final Trump-Clinton Debate Transcript, Annotated. The Washington Post. From https://www.washingtonpost.com

Bouchard, K. L. \& Smith, D. J. (2017). Teacher-student Relationship Quality and Children's Bullying Experiences with Peers: Reflecting on the Mesosystem. The Educational Forum, 81, 108-125.

https://doi.org/10.1080/00131725.2016.1243182.

Brinkley, L. (2016, 25 October). 'Build the Wall Higher' Graffiti Investigated as Hate Crime. $A B C 7$. From https://abc13.com/school-graffiti-'build-the-wall-higher'at-windsor-being-investigated-as-hate-crime/1571673/

Bronfenbrenner, U. (1977). Toward an Experimental Ecology of Human Development. American Psychologist, July, 513-531.

Bronfenbrenner, U. (1979). The Ecology of Human Development: Experiments by Nature and Design. Cambridge: Harvard University Press.

C-Span (2015, 24 January). Iowa Freedom Summit, Donald Trump. C-Span. From https://www.c-span.org/video/?3238347/iowa-freedom-summit-donald-trump

Carrera, M. V., DePalma, R. \& Lameiras, M. (2011). Toward a More Comprehensive Understanding of Bullying in School Settings. Educational Psychology Review, 23, 479-499. https://doi.org/10.1007/s10648-011-9171-x.

Carroll, R. (2016, 9 June). 'You Were Born in a Taco Bell': Trump's Rhetoric Fuels School Bullies Across US. The Guardian. 
From https://www.theguardian.com/usnews/2016/jun/09/california-primary-trump-rhetoricschool-bully

CBS Detroit (2016, 20 September). The 'Trump Effect': Bullying, Fear on the Rise for School Kids. CBS Detroit. From https://detroit.cbslocal.com/2016/09/20/the-trumpeffect-bullying-fear-on-the-rise-for-school-kids/

CBS New York (2016, 11 April). Wisconsin Students Chant at Latina Female Soccer Players: 'Donald Trump, Build that Wall!' CBS New York. From https://newyork.cbslocal.com/2016/04/11/wisconsinsoccer-trump-chant/

CNN (2015, 1 July). Donald Trump: 'Somebody's Doing the Raping' (CNN Interview with Don Lemon). CNN. From https://www.youtube.com/watch?v=206Nmx kZMQ

Costello, M. B. (2016a). Teaching the 2016 Election: The Trump Effect. The Impact of the Presidential Campaign on our Nation's Schools. Montgomery: Southern Poverty Law Center.

Costello, M. B. (2016b). After Election Day: The Trump Effect. The Impact of the 2016 Presidential Election on our Nation's Schools. Montgomery: Southern Poverty Law Center.

Crombie, N. (2016, 19 May). Forest Grove High Students Walk Out Over 'Build a Wall' Banner. The Oregonian. From https://www.oregonlive.com/forestgrove/2016/05/forest grove high students pla.html

Crowley, M. (2016, 10 August). Trump's Long Dalliance with Violent Rhetoric. Politico. From https://www.politico.com/story/2016/08/trump-violentrhetoric-history-226873

Cuevas, M. (2016, 1 March). 'Trump' as Anti-Latino Epithet: Ugly Incidents at High School Games. CNN. From https://edition.cnn.com/2016/03/01/us/midwest-trumpschool-chants/index.html

Donovan, E. (2016, 4 June). Latino Students Upset Over McDowell Prank; Seniors Won't Face Disciplinary Action. WLOS. From https://wlos.com/news/local/latino-students-upset-overmcdowell-prank-seniors-wont-face-disciplinary-action 
Durr, M. (2016, 10 November). DeWitt Junior High Students Formed Wall to Block Minorities. Michigan Live. From https://www.mlive.com/news/2016/11/students at dewi tt school form.html

Espelage, D. L. \& Swearer, S. M. (2010). A Social-Ecological Model for Bullying Prevention and Intervention. Understanding the Impact of Adults in the Social-Ecology of Youngsters." In S. R. Jimerson, S. M. Swearer \& D. L. Espelage (Eds.), Handbook of Bullying in Schools: An International Perspective (61-72). New York, NY: Routledge.

Fairclough, N. (2010). Critical Discourse Analysis: The Critical Study of Language. Second edition. Harlow: Pearson.

Fox 10 Phoenix (2016, 25 May). 'Build that Wall!' Donald Trump Chants after Major Endorsement. Fox10 Phoenix. From https://www.youtube.com/watch?v=ZGSAhNZnisk

Foucault, M. (1981). The Order of Discourse. Inaugural Lecture at the Collége de France, Given 2 December 1970. Translated by Ian McLeod. In R. Young (Ed.), Untying the Text: A PostStructuralist Reader (49-78). Boston, MA: Routledge \& Kegan Paul.

Fuller, K. (2016, 26 May). Hilhi, Other Schools See Students March in Solidarity. Hillsboro News Times. From https://pamplinmedia.com/ht/117-hillsboro-tribunenews/308932-185970-hilhi-other-schools-see-studentsmarch-in-solidarity?wallit nosession=1

Goffman, E. (1983). The Interaction Order: American Sociological Association, 1982 Presidential Address. American Sociological Review, 48(1), 1-17. https://www.jstor.org/stable/2095141.

Herman, L. (2016, 30 December). The 12-Year-Old Student Whose 'Build a Wall' Video Went Viral Left School After Extreme Backlash. Teen Vogue. From https://www.teenvogue.com/story/the-12-year-oldstudent-whose-build-a-wall-viral-video-left-school-afterextreme-backlash

Hirschfeld Davis, J. \& Baker, P. (2019, 5 January). The Border Wall: How a Potent Symbol is Now Boxing Trump In. The New York Times. From https://web.archive.org/web/20190105235710/https:// 
www.nytimes.com/2019/01/05/us/politics/donaldtrump-border-wall.html

Hong, J. S. \& Espelage, D. L. (2012). A Review of Research on Bullying and Peer Victimization in School: An Ecological System Analysis. Aggression and Violent Behavior, 17, 311322. https://doi.org/10.1016/j.avb.2012.03.003.

Horton, P. (2016a). Unpacking the bullying doll: Reflections from a fieldwork at the social-ecological square. Confero: Essays on Education, Philosophy and Politics, 4(1), 71-95.

Horton, P. (2016b). Portraying monsters: Framing school bullying through a macro lens. Discourse: Studies in the Cultural Politics of Education, 37(2), 204-214.

Huang, F. L. \& Cornell, D. G. (2019). School Teasing and Bullying after the Presidential Election. Educational Researcher, 48(2), 69-83.

https://doi.org/10.3102/0013189X18820291.

Human Rights Campaign Foundation (2017). Post-Election Survey of Youth. Washington DC: Human Rights Campaign Foundation.

Iannetta, G. (2016, 26 April). 'Build that Wall': Westbrook Students Paint Trump Support on School 'Spirit' Rock. NBC Connecticut. From https://www.nbcconnecticut.com/news/local/build-thatwall-westbrook-students-paint-trump-support-on-schoolspirit-rock/111890/

Jacobo, J. (2016, 10 November). Students Chant 'Build the Wall' at Middle School Cafeteria the Day After the Election. $A B C$ News. From https://abcnews.go.com/US/students-chantbuild-wall-middle-school-cafeteriaday/story?id=43451771

Jamieson, A. (2016, 20 November). 'They are Scared': Teachers Grapple with Fear and Bullying after Trump Victory. The Guardian. From https://www.theguardian.com/usnews/2016/nov/20/donald-trump-schools-electionstudents-bullying

Johnson, K. R. (2010). It's the Economy, Stupid: The Hijacking of the Debate Over Immigration Reform by Monsters, Ghosts, and Goblins (or the War on Drugs, War on Terror, Narcoterrorists, Etc.). Chapman Law Review, 13(3), 583- 
614. https://digitalcommons.chapman.edu/chapman-lawreview/vol13/iss $3 / 4 /$

Johnson, M. (2017). Trickle-down Bullying and the Truly Great American Response: Can Responsible Rhetoric in Judicial Advocacy and Decision-Making Help Heal the Divisiveness of the Trump Presidency. Journal of Gender, Social Policy \& The Law, 25(4), 445-508.

https://papers.ssrn.com/sol3/papers.cfm?abstract id=306 $\underline{3639}$

Jones, S. (2016, 3 October). Teachers Alarmed that Trump's Behavior is Causing Increased Bullying in US Schools. Politicus. From

https://www.politicususa.com/2016/10/03/concernedteachers-speak-alarming-trend-bullying-call-trumpeffect.html

Jørgensen, M. \& Phillips, L. (2002). Discourse Analysis as Theory and Method. Los Angeles: Sage.

Kristof, N. (2016, 13 August). Donald Trump is Making America Meaner. The New York Times. From https://www.nytimes.com/2016/08/14/opinion/sunday/ donald-trump-is-making-america-meaner.html

Lanktree, G. (2016, 11 November). Schoolchildren Begin Building Trump's Wall as Racial Bullying Surges in the Classroom. International Business Times. From https://www.ibtimes.co.uk/school-children-have-begunbuilding-trumps-wall-racial-bullying-surges-classroom$\underline{1591042}$

Latimer, B. (2016, 12 September). Backlash After Students Build Trump 'Wall' at High School Rally. NBC Dallas-Fort Worth. From https://www.nbcnews.com/news/latino/backlashafter-students-build-trump-wall-high-school-rally$\underline{\mathrm{n} 646791}$

Loeb, H. (2016, 27 August). Donald Trump and the Crisis of Bullying. The Huffington Post. From https://www.huffpost.com/entry/donald-trump-and-thecris b 8039918? guccounter $=1$

Mansoor, S. (2016, 11 November). Students at Plan East Allege Racial Slurs After Trump Victory. The Dallas Morning News. From 
https://www.dallasnews.com/news/education/2016/11/ $\underline{11 / \text { students-at-plano-east-allege-racial-slurs-after-trump- }}$ victory/

McDonald, M. (2016, 9 November). School District Responds after Utah Students Harassed Following Trump Victory. Fox 13. From https://fox13now.com/2016/11/09/school-districtresponds-after-utah-students-bullied-following-trumpvictory/

McLeod, J. R. (1999). The Sociodrama of Presidential Politics: Rhetoric, Ritual, and Power in the Era of Teledemocracy. American Anthropologist, 101(2), 359-373. https://doi.org/10.1525/aa.1999.101.2.359.

Mehan, H. (1997). The Discourse of the Illegal Immigration Debate: A Case Study in the Politics of Representation. Discourse \& Society, 8(2), 249-270. https://doi.org/10.1177/0957926597008002006.

Meyer, E. J. (2016, 13 November). Why School Climate Matters with a President Trump. Psychology Today. From https://www.psychologytoday.com/us/blog/gender-andschooling/201611/why-school-climate-matters-presidenttrump

Miller, A. (2017, 9 February). Anti-Hispanic Harassment has Increased Since Election. Albany Herald. From https://www.albanyherald.com/news/local/anti-hispanicharassment-has-increased-since-election/article bfe45a363327-52ad-8917-0221ad4dd9c0.html

Parks, C. (2016, 23 May). Fed Up with Anti-Latino Sentiment, Hundreds of Portland High Schoolers Leave Class. The Oregonian. From https://www.oregonlive.com/education/2016/05/portlan d latino students prote.html

Santos, R. (2016, 11 November). NBISD Students Accused of Chanting 'Build a Wall' on a Bus Could Face Disciplinary Action. Fox San Antonio. From https://foxsanantonio.com/news/local/nbisd-studentsaccused-of-chanting-build-a-wall-on-a-bus-could-facedisciplinary-action

Schilken, C. (2016, 26 February). In Iowa, Students Chant 'Trump! Trump!' after Basketball Loss to More Racially Diverse High 
School. Los Angeles Times. From

https://www.latimes.com/sports/sportsnow/la-sp-sntrump-chant-20160226-story.html

Schwartzmann, P. \& Miller, M. E. (2016, 22 June). Confident.

Incorrigible. Bully: Little Donny was a Lot Like Candidate

Donald Trump. The Washington Post. From

https://www.washingtonpost.com/lifestyle/style/youngdonald-trump-military-school/2016/06/22/f0b3b164-

317c-11e6-8758-d58e76e11b12 story.html

Seltzer, V. J. (2016, 29 September). Action on Warsaw Football

Field Overshadowed by Controversial Tweets. WSBT 22.

From https://wsbt.com/news/local/action-on-warsaw-

football-field-overshadowed-by-controversial-tweets

Sprague, J. (2016, 9 November). Why the Trump Effect Could

Increase Bullying. The Conversation. From

https://theconversation.com/why-the-trump-effect-couldincrease-bullying-67831

Stafford, K. (2016, 10 November). Michigan Students Chant 'Build the Wall' in Viral Video. USA Today. From https://eu.usatoday.com/story/news/nationnow/2016/11/10/michigan-students-chant-buildwall $/ 93589770 /$

Tan, A. (2016, 26 October). 'Build the Wall Higher' Graffiti Found at California School with 'Large Latino Population,' Police Say. ABC News. From https://abcnews.go.com/US/buildwall-higher-graffiti-found-california-schoollarge/story?id=43070252

Transcript of the Second Debate (2016, 10 October). The New York Times. From https://www.nytimes.com/2016/10/10/us/politics/trans cript-second-debate.html? $r=1$

Van Dijk, T. A. (1993). Principles of Critical Discourse Analysis. Discourse \& Society, 4(2), 249-283. https://doi.org/10.1177/0957926593004002006.

Walker, H. (2015, 6 July). Donald Trump Just Released an Epic Statement Raging Against Mexican Immigrants and 'Disease'. Business Insider UK. From https://www.businessinsider.com/donald-trumps-epicstatement-on-mexico-2015-7? r=US\&IR=T 
Wallace, K. \& LaMotte, S. (2016, 28 December). The Collateral Damage after Students' 'Build a Wall' Chant Goes Viral. CNN. From https://edition.cnn.com/2016/12/28/health/builda-wall-viral-video-collateral-damage-middleschool/index.html

Walton, G. (2011). Spinning our Wheels: Reconceptualising Bullying Beyond Behaviour-Focused Approaches. Discourse: Studies in the Cultural Politics of Education, 32(1), 131-144. https://doi.org/10.1080/01596306.2011.537079.

Walton, G. (2015). Bullying and the philosophy of shooting freaks. Confero: Essays on Education, Philosophy and Politics, 3(2), 17-35.

Washington Post Editorial Staff (2016, 31 May). Donald Trump, Bully in Chief. The Washington Post. From https://www.washingtonpost.com/opinions/bully-inchief/2016/05/31/8658640a-2762-11e6-ae4a3cdd5fe74204 story.html

Washington Post Staff (2015, June 16). Full Text: Donald Trump Announces a Presidential Bid. The Washington Post. From https://www.washingtonpost.com/news/postpolitics/wp/2015/06/16/full-text-donald-trumpannounces-a-presidential-bid/ 
Paul Horton is an Associate Professor in Education at the Department of Behavioural Sciences and Learning (IBL), Linköping University, Sweden. His research is particularly interested in school bullying and the importance of the social, institutional and societal contexts within which it occurs. He has previously written about school bullying in the Danish, New Zealand, Vietnamese and Swedish school contexts, and his publications include the book, Bullied into it: Bullying, Power and the Conduct of Conduct, which is part of the Ethnography and Education book series.

The terms and conditions of use are related to Creative Commons Attribution Licence (CC-BY) 